\title{
ПРИДАВКАТА LIВЕR И НЕЈЗИНИТЕ ИЗВЕДЕНКИ ВО ИГРИТЕ СО ЗБОРОВИ КАЈ ПЛАУТ
}

\section{Кратка содржина}

Придавката līber, „слободен“, којашто произлегува од индоевропскиот корен * $H_{l} l$ leudh-, , раснам, се издигнувам“ " и зборовите изведени од неа, како lībertas, , слобода“, lībertus и lībertīnus, „ослободеник“, lībero, „ослободувам“, līberālis, „слободен, благороден, дарежли““, līberī, „деца“", Lìber, „Либер, Ослободител" имаат значајна улога во создавањето игри со зборови кај римскиот комедиограф Плаут. Анализата на примерите покажува дека овие зборови, од една страна, Плаут ги користи за да создаде смешни ситуачии на недоразбирање, кое произлегува од нивната повеќезначност. Од друга страна, тој ги става во релачија со други зборови кои не се етимолочки поврзани со нив, но звучат слично. Вториот тип игри со зборови се важно сведочтво за семантичкиот развој на придавката līber и нејзините изведенки во ранолатинскиот, но и за дополнителна анализа на разбирањето на поимот ,слобода“ кај Латините.

Клучни зборови: LIBER, ПЛАУТ, ИГРИ СО ЗБОРОВИ

Tеоп.: Момче, си одии, а? Фан: Слободата е наметка за твојот грб: а мојот, ако не се грижам за господарот, ке остане отскриен.

(Pl.Most. 991-992)

Придавката līber, „слободен“ произлегува од индоевропскиот корен * $H_{1} l e u d h-$, „раснам, се издигнувам“, сп. скт. ródhati, „расне, се издигнува“, грч.

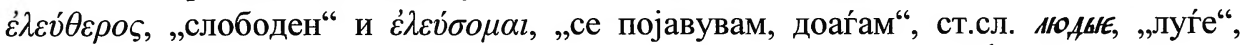
литв. liáudis, „народ, луѓе“, гот. liudan, „расне“, ст.в.г. liut, „луѓе“. ${ }^{\prime}$

Од придавката līber во латинскиот се изведени повеќе зборови со исто значење, како што се lībertas, „слобода“, lībertus и lïbertīnus, „ослободеник“, lībero, „ослободувам“, līberālis, „слободен“ или со различно значење, како именката līberī, „деца“, а тука е и теонимот Līber, бог на вегетацијата и плодноста, всуш-

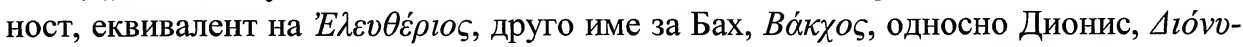
боৎ. Семантичката разнообразност во латинскиот сведочи за семантичкиот развој на коренот ${ }^{*} H_{l} l e u d h$ - во рамките на индоевропските јазици од „раснам, се издигнувам“ до „поколение, народ, луѓе“", па до „слободен, оној што му припаѓa на својот род, а не на туѓите или покорените родови и племиња, оној што се наоѓa меѓу

${ }^{1}$ EDL 338; EDSIL 282; EDG I 408 и IEW 684-685; БEP III 577. 
своите сонародници“ и „дете, пород, потомок на слободните луѓе, законски припадник на родот“ (Benveniste, 1969 : 323-324).

Темата на слободата во Плаутовите комедии постојано се провлекува низ приказните за робовите, воените заробеници, робинките ослободени за да бидат љубовници на богатите синови. ${ }^{2}$ Односот роб - господар зазема важно место во комедијата, ${ }^{3}$ а важна тема е и слободното однесување во еротска смисла. Оттаму, не е изненадувачки што придавката liber, „слободен“, именката libertas, „слобода“ и другите зборови изведени од основата lib-ero- се среќаваат често кај Плаут. Од една страна, тие се јавуваат во реплики со морализаторски тон низ кои се открива сериозноста и длабочината на инаку комичните ликови, а од друга страна, во игри со зборови, каде што досетливоста станува предмет на забава. Во ова истражување предвид се земени само игрите со зборови.

\section{Liberalis - libero}

Во наједноставна форма игрите со зборови кај Плаут претставуваат figura etymologica. Еден пример каде што глаголот libero, „ослободувам“ и придавката liberalis, „слободен, слободарски, благороден, љубезен, дарежлив“ се употребени непосредно едно по друго, во истата реченица има во комедијата, „Куркулион“, сп. P1.Cur.208-209:

Phaed. Ita me Venus amet, ut ego te hoc triduom numquam sinam in domo esse istac, quin ego te liberalem liberem.

Фаед. Жими Венера, ни три дни тука да минеш нема да дозволам, ти слободна овде, во овој дом, да бидеш а, да не те ослободам јас. ${ }^{4}$

Но, тука сепак не се работи само за едноставно повторување на два збора изведени од иста основа, туку има и игра која произлегува од нивната повеќезначност. Од контекстот покрај значењето „слободен“ односно „благороден, достоен за слободните граѓани“, може да произлезе и едно друго значење „опуштен, во смисла слободен за доживување задоволства“. Имено, разговорот што се води во третата сцена од првиот чин е разговор помеѓу двајца заљубени, Фаедром и Планесија, робинка, која на крајот, сепак, ке се покаже дека има потекло од слободни родители и дека е liberalis. Па, така стиховите 208-209 можат да се преведат и на следниов начин:

Фаед. Жими Венера, ни три дни тука да минеш нема да дозволам, ти овде, во овој дом, да бидеш, а опуштена, да не си, не те пуштам јас.

\footnotetext{
2 За историското значење на книжевното сведоштво на Плаут за ропството и слободата, види Stewart, 2012 : 132-155, 164-189.

3 За можноста овој однос во Плаутовите комедии да се анализира како однос на секој човек кон потчинувањето и доминацијата во универзална смисла, види McCarthy, 2000 : 17-29.

${ }^{4}$ Доколку не е поинаку назначено препевот на стиховите е на авторката.
} 


\section{Liber - liberi}

Предмет на семантичка игра кај Плаут може да бидат и придавката liber, „слободен“ и именката liberi, „деца“. Така, во „Војникот фалбаџија“, во првата сцена од третиот чин, во стиховите 682-683 разговараат Палајстрион, роб на Плевсикле, младо момче од Атина и Периплектомен, постар господин од Ефес:

Pal. Cur non vis? nam procreare liberos lepidumst onus.

Per. Hercle vero liberum esse tete, id multo lepidiust.

Пал. Зошто не сакаш? Слободни чеда да створиш, товар сладок е.

Пер. Жими Херкула, самиот слободен да бидеш, многу послатко e. $^{5}$

Играта со зборови овде произлегува од двозначноста на формата liberum, која може да се сфати и како акузатив еднина од придавката liber, „слободен“ и како генитив множина од именката liberi, „деца“, односно придавката liber. ${ }^{6}$ Ако се земе предвид второто значење, стихот 683 може да се преведе и на следниов начин:

Пер. Жими Херкула, меѓу слободни да бидеш, многу послатко е.

\section{Liber - liber}

Во комедијата „Заробеници“ во четвртата сцена од третиот чин, Аристофонт, заробеник, ја разоткрива пред Хегион, негов господар, измамата на Тиндар, роб заробеник, кој се претставува лажно како да е Филократ неговиот господар, кој е исто така заробеник на Хегион. За да се извлече Тиндар си поигрува со Аристофонт и му вели, сп. Pl.Capt. 577-578:

Arist. Quid ais, furcifer? tun te gnatum $<$ esse $>$ memoras liberum?

Tynd. Non equidem me Liberum, sed Philocratem esse aio. A. Quid est?

Арист. Што велиш, несреќо? Тврдиш дека ти си роден слободен?

Тинд. Не велам дека јас сум Слободан, туку Филократ. Арист. Како бе? ${ }^{7}$

Комичниот ефект овде се постигнува со употребата на формата liberum во контекст кој дозволува таа да се протолкува и како акузатив еднина од придавката liber, „слободен“, но и како акузатив еднина од теонимот Liber, Либер, Ослободи-

${ }^{5}$ Сп. го и препевот на М. Бузалковска Алексова во изданието Т. М. Плаут, „Војникот фалбаџија“, Скопје 2007: „Пал. Зошто не сакаш? Да се создадат деца е прекрасна обврска./ Пер. Жими Херкула, навистина е многу попрекрасно да бидеш слободен.“.

${ }^{6}$ Иако, именките со о-основа во генитив множина вообичаено завршуваат на -оrum, кај некои именки се зачувала постарата наставка за генитив множина -ит, како кај именките со консонантска основа, сп. ранолатински leiberum, види Meiser, 2006 : 134; Leumann, 1977 : 428.

${ }^{7}$ Сп. и го препевот на М. Бузалковска Алексова во изданието Т. М. Плаут, Комедии, Скопје 2003: „Арист. Што зборуваш, измамнику? Ти ми кажуваш дека си бил роден како слободен?/ Тинд. Не велам дека се викам Слободен, туку Филократ. Арист. Што е ова?“ 
тел, Слободан. ${ }^{8}$ Но, за комичното недоразбирање придонесува и тоа што различно може да се интерпретира и синтаксичката конструкција, во зависност од тоа како ќе се поврзат акузативите со инфинитивот од глаголот „сум“. Така што реченицата Non equidem me Liberum, sed Philocratem esse aio може да значи и: „Не велам дека јас сум слободен, туку дека Филократ е слободен.“, со што се создава можност Хегион да не ја открие измамата на Тиндар и со тоа драмската напнатост продолжува. Имајќи го предвид второво толкување, стихот 578 може да се преведе:

Тинд. Не велам дека јас сум слободен, туку Филократ. Арист. Како бе?

\section{Liber - liber - liberalis - lepos, lepidus - locus}

Зборовите изведени од основата lib-ero- во комедиите на Плаут се доведуваат во семантички врски и со зборови со кои не се етимолошки поврзани. Така, придавката liber, теонимот Liber и придавката liberalis, којашто значи „слободен, благороден“", но и „дарежлив, љубезен“, на повеќе места во комедиите на Плаут се поврзуваат со именката lepōs (lepor), „пријатност, милост, нежност, слаткост, сладина“ и придавката lepidus, „пријатен, мил, нежен, сладок“. Lepos и lepidus може

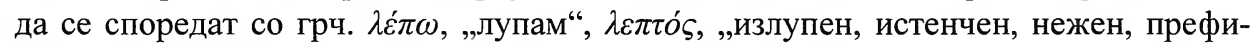
нет“, литв. lãpas, латв. lapa, „лист“, литв. lepùs, „слаб, мек“ од протоиндоевропскиот корен *lep/lop-, ,лупам“.9

Во „Куркулион“, Фаедром се обидува со вино да ја поткупи, старицата Леајна, која ја чува куќата на трговецот со робови Кападокс, за да му дозволи да се сретне со Планесија, една од робинките во која е вљубен. Привлечена од мирисот на виното, старицата му се обраќа на бокалот, сп. Pl. Cur. 99-100:

salve, anime mi, Liberi lepos.

ut veteris vetus tui cupida sum.

Здраво, душо, сладино, слободо.

Стара, а копнеам по староста твоја.

Дека синтагмата Liberi lepos, „слаткост, сладина на Ослободителот“, синоним за виното, за Плаут не е само звучна стилска фигура, туку дека меѓу двата збора се воспоставува и семантичка врска сведочи паралелната синтагма veteris vetus tui, во следниот стих. Имено, гледано од морфолошки аспект, формата vetus, номинатив од именката vetus, „старост“ е во паралелен сооднос со формата lepos, номинатив од именката lepor, „слаткост, сладина, пријатност, нежност“, додека формата veteris, генитив од vetus е во паралелен сооднос со Liberi, генитив од теонимот Liber, Либер, Ослободител. Вака поставениот формален дијаграм е подлога за развивање на алегорична слика: Либер е бог на виното, виното е послатко кол-

\footnotetext{
${ }^{8}$ За да се пренесе на македонски играта со зборови, теонимот Līber може да се преведе и

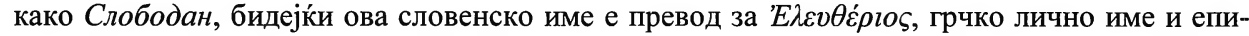
тет на богот Дионис.

${ }^{9} E D L 335$; IEW 678. Но, Бекс не се согласува со оваа етимологија и смета дека грчките зборови, всушност, се предгрчки, види $E D G I 849$.
} 
ку што е постаро, старицата, којашто обожава да пие вино е послатка колку што пие повеќе од виното, зашто виното дава слобода (Duckworth, 1994: 326). Алегоријата продолжува и неколку стиха подолу, каде што во стихот 116 Фаедром се претставува пред старата сводничка како vinipollens lepidus Liber, „Господарот на виното, слаткиот Ослободител“.

На повеќе места во своите комедии Плаут ја користи фразата forma lepida et liberali, „со мил и благороден изглед“, кога зборува за девојки робинки во кои се заљубуваат богати слободни момчиња, па ги ослободуваат со откупување за да се оженат со нив, сп. P1.Epid.43-44; Per.130; Mil.967. Латинската фраза има паралела во комедиите на Менандар, каде што добрата девојка се опишува како є́ $\lambda \varepsilon v \theta \varepsilon \dot{-}$

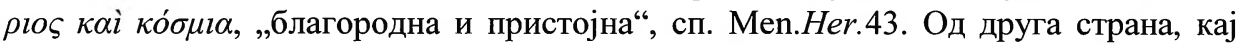

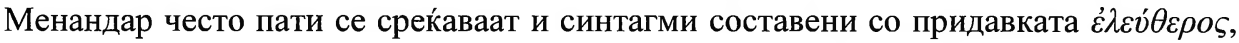

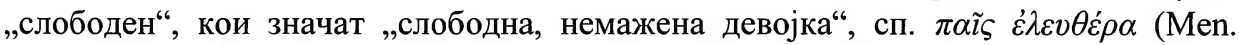

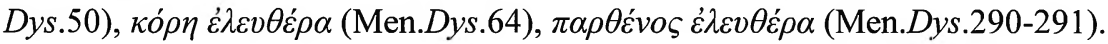

Сепак, кај Плаут врската помеѓу придавките lepidus и liberalis не е само алитерација и асонанца. Во комедијата „Псевдол“, стариот Калифон го убедува својот пријател Симон да има разбирање за својот син, којшто бара пари за да ја ослободи заробената девојка во која се вљубил, а робот Псевдол го прислушкува овој разговор и коментира, сп. Pl.Ps.434-435:

quid mirum fecit? quid novom, adulescens homo si amat, si amicam liberat? Ps. Lepidum senem.

И што сторил чудно? Нешто ново е, момче младо, саканата да сака да ја ослободи? Пс. Сладок е стариов.

Придавката lepidus не е случајно употребена во непосредна близина на глаголот libero, старецот кој има разбирање за ослободувањето робинки е сладок, односно мил, така како што е слатка и мила слободата, така како што се слатки слободните девојки, слободни затоа што се благородни, но и во еротска смисла.

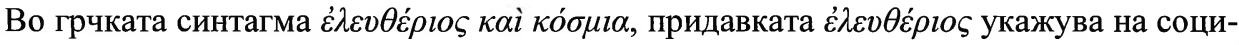
јалниот статус на девојката, дека таа е достојна да стане жена на слободен маж, а придавката ко́бцьоৎ дека таа е убаво стокмена, накитена со внатрешни и надворешни квалитети, што секој маж би ги посакал. Во латинската синтагма forma lepida

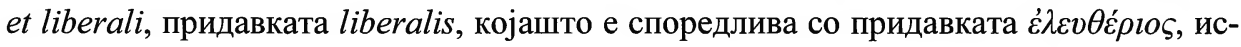
то така, укажува на социјалниот статус на девојката, дека е таа достојна да стане жена на слободен маж, а придавката lepidus, исто како и придавката ко́б $\mu \iota \varsigma$, на нејзините квалитети, но играта со зборови покажува дека тоа се во прв план надворешните квалитети, еротската привлечност. Имајќи го предвид ова метафоричко значење на придавката lepidus, јасно е како придавката liberalis го добива значењето „опуштен“ (види претходно).

Во една друга игра со зборови се покажува дека и придавката liber исто како и придавката liberalis го поприма значењето „опуштен, отворен и подготвен за доживување задоволства“ во близина на придавката lepidus, сп. Pl. Bac. 79-84: 
Pist. Quid si apud te eveniát desubito prandium aut potatio forte aut cena, ut solet in istis fieri conciliabulis, ubi ego tum accumbam? Bacch. Ápud me, mi anime, ut lepidus cum lepida accubet.

locus hic apud nos, quamvis subito venias, semper liber est. ubi tu lepide vóles esse tibi, méa rosa, mihi dicito 'dato qui bene sit': ego ubi bene sit tibi locum lepidum dabo.

Пист. Ако ненадејно се случи кај тебе доручек или пиенка или пак вечера да има, како што обично бива на собири, каде да прилегнам? Бакх. Кај мене, душичке, сладок со слатка ќе прилегне.

Ова седало, и ненајавен да дојдеш, кај нас, секогаш е слободно.

Кога ќе посакаш слатко да ти биде, ружичке, само кажи ми „дај да ми биде добро“: и добро, седало слатко, ќе ти дадам јас.

Во овој разговор помеѓу Пистоклер, младо момче заљубено во Бакхида, девојка што работи во јавна куќа, еротската конотација е сосема јасна. Преку звучното поврзување на зборовите lepidus, liber и locus, Плаут постигнува и семантичка игра. Синтагмата locus liber, „слободно место за седење покрај трпезата“, имајќи го предвид глаголот accubo, „лежам, прилегнувам покрај масата за седење“, станува „слободно место за прилегнување, односно слободно место за телесна блискост“, затоа што е во исто време locus lepidus, „прекрасно, нежно, слатко место“. Синтагмата locus liber и во други комедии на Плаут го има истото преносно значење, сп. Pl.Cas. 537; Poen. 177, 602, 657; St. 662.

\section{Libertas - liber - libella}

Во петтата сцена од вториот чин од комедијата „Касина“, Олимпион, роб на Лисидам во една расправија со Клеострата, жена на Лисидам, која му врши притисок да не се жени со Касина, љубовница на нејзиниот маж, вели, сп. Pl. Cas.312-317:

Ol. Quid tu me tua, era, libertate territas?

qui si tu nolis filiusque etiam tuos, vobis invitis atque amborum ingratiis una libella liber possum fieri.

Ол. Господарке, зошто ме плашиш со твојата слобода?

И ако е против волјата твоја и на твојот син, и без одобрување и согласност од вас двајцата, за една стотинка можам да бидам слободен.

Очигледно е дека овде се спротивставуваат по своето значење именката libertas, „слобода“, која во дадениот контекст има поконкретно значење „слобода да правам што сакам, слобода да се заканувам“ и придавката liber, „слободен“, која во истиот контекст има значење „слободен да правам што сакам, односно сло- 
бода да не бидам повеќе роб, ослободен“. Именката libella, деминутив од libra, „монета, десетти дел од денариј“, која овде има општо значење „мала сума на пари“, освен тоа што звучно се надоврзува на придавката liber, помага да се воспостави семантичката врска помеѓ libertas и liber. Парите се клучот за стекнување на слободата, а во случајот на робот Олимпион, кој ја има благонаклонетоста на својот господар, доволна ќе биде и само една стотинка. Имено, планот на господарот Лисидам е да ја ожени Касина за Олимпион, за да има слободен пристап до неа како љубовница. Зборот lìbra не е етимолошки поврзан со придавката lïber, туку произлегува од една протоиталска основа *leiPra-, ,мерка за тежина“. ${ }^{10}$

\section{Liber - lubentius}

Во некои сцени игрите со зборови кај Плаут се состојат во воспоставување семантичка релација помеѓу придавката liber и глаголот libet, ранолат. lubet, „ми годи, ми се допаѓа, сакам“ или libentius, ранолат. lubentius, компаратив од прилогот libenter, „со задоволство“ иако помеѓу овие зборови нема етимолошка врска. ${ }^{11}$ Така, во комедијата „Заробеници“" во втората сцена од првиот чин Хегион, сопственик на заробеници и робови, му дава инструкции на надзорникот како да се погрижи за заробените, сп. Pl.Capt.116-121:

liber captivos avis ferae consimilis est:

semel fugiendi si data est occasio, satis est, numquam postilla possis prendere.

Lor. Omnes profecto liberi lubentius sumus quám servimus. Heg. Non videre ita tu quidem.

Lor. Si non est quod dem, mene vis dem ipse-in pedes?

Заробеник слободен на птица дива налик е.

И само еднаш, ако му се даде прилика

Ќе избега веднаш и нема да можеш да го прибереш.

Надзор.: Се разбира сите повеќе сакаме слободни

да бидеме, а не робови. Хег. Но, не му даваш важност на нештово ти.

Надзор.: Штом немам што да дадам, да не сакаш самиот да се вдадам? ${ }^{12}$

${ }^{10}$ EDL 339 ; Untermann, $2000: 828$.

${ }^{11}$ Глаголот libet е од протиндоевропскиот корен *leubh-, „ми причинува задоволство, посакувам, имам желба“, сп. скт. lúbhyati, „гори од желба, силно посакува“ и löbha-, „желба“, гот. liufs, „љубов“, galaufs, „посакуван“, ст.норд. lof, „восхит, допуштање, дозвола“ и leyfa, „допушта, се восхитува“, литв. liaupsê,, „восхит“ и liáupsinti, „се восхитува“, мюбнтн, „љуби“ и люв"', „љубов“, види IEW 683-684; EDL 338-339; БEP III 572, 575-576; EDSIL 281.

${ }^{12}$ Сп. го и препевот на М. Бузалковска Алексова во изданието Т.М.Плаут, Комедии, Скопје, 2003: „Слободниот заробеник е како дива птица/ ѝ се даде ли можност еднаш да ти избега,/ ќе биде доста - нема да ја фатиш веќе никогаш./Лор. Се разбира, сите повеќе ја сакаме слободата од ропството./Хег. А ти пак, за таков ич, не ми личиш./Лор. Ако нема што да ти дадам, да ти удрев едно „со здравје“?“. 
Баналниот разговор помеѓу господарот и надзорникот на заробениците, кој и самиот е роб, се претвора во суптилна дискусија за тоа што го држи, всушност, робот кај господарот, оковите или немањето прилика за ослободување. Употребата на прилогот lubentius во непосредна близина на придавката liber е повеќе од соопштување на општопознатата фраза дека сите посакуваме слобода. Прилогот lubentius нѐ насочува на играта со зборови што следува во стиховите 120-121 co videre, инфинитив од глаголот video, „гледам, внимавам, се грижам“ и dem, конјунктив од $d o$, „давам“, quidem, „навистина, секако“, pes, „нога“ односно синтагмата se dare in pedes, „се вдавам в бегство, фаќам магла“ (McCarthy, $2000: 184$ 185). Формите за прво и второ лице конјунктив од глаголот „давам“ dem, ,jac би дал“" и des, „ти би дал“ може да се препознаат во quidem и во pedes, а qui може да биде и адверб quі со инструменталско-аблативско значење, „со (не)што, од (не)што“. Така дијалогот помеѓу господарот и робот може да се протолкува како разговор за задоволството, иако формално она што господарот ветува дека ќе му го даде на робот доколку побегне е ќотек и кафез, сп. ги и стиховите што следуваат 122 -125. Имајќ ја предвид оваа игра со зборови, фразата liberi lubentius sumus можеме да ја разбереме и како „повеќе сакаме да бидеме деца“, зашто liberi може да се сфати и како форма од именката „деца, момчиња“, а синтагмата in pedes може да

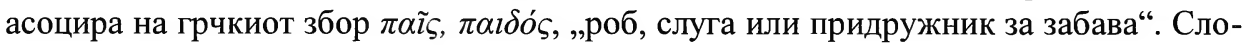
бодни сме тогаш кога ќе му се препуштиме на задоволството, а тоа најдобро го знае оној што нема што друго да даде за да си ја плати слободата освен себеси.

\section{Libere - licet - loqui}

Во комедијата „Амфитрион“, во првата сцена од првиот чин, Сосија, робот на Амфитрион, се упатува кон куќата на својот господар во Теба, во доцните ноќни часови за да го најави неговото враќање. Но, пред куќата наидува на богот Меркур, кој е преправен како да е самиот тој, Сосија, затоа што во исто време неговиот татко богот Јупитер, преправен како Амфитрион, е кај Алкмена, жената на Амфитрион. Меркур го напаѓa физички Сосија и го убедува дека тој самиот е Сoсија и тука настанува една комична ситуација, во која вистинскиот Сосија се обидува да се спаси, така што ќе признае сѐ што се бара од него, сп. Pl.Am.393-394:

Sos. Animum advorte. nunc licet mihi libere quidvis loqui.

Amphitruonis ego sum servos Sosia. Merc. Etiam denuo?

Сос. Внимавај ваму. Допуштено ми е сега да соопштам што сакаш опуштено.

Јас сум Сосија, робот на Амфитрион. Мер. Што е сега, повторно?

Во оваа игра со зборови звучниот ефект се постигнува со употребата на зборовите licet, „допуштено е, важи, може“, libere, адверб од придавката „слободен, опуштен“ и loqui, инфинитив од глаголот loquor, „зборувам“ кои не се меѓу- 
себно етимолошки поврзани. ${ }^{13}$ Повеќезначноста и комичниот ефект се постигнува со употребата на зборот quidvis, „што сакаш, било што, нешто“, супстантивизирана форма од општата и неопределена заменска придавка quivis, quaevis, quodvis, „кој, -a, -е сакаш, кој, -a, -е и да е“, што може да значи буквално „што сакаш ти““, ${ }^{14}$ но и преносно „што сака кој било“, „што и да е“. Во дијалогот што претходи синтагмата quid vis ја употребува Меркур, кога се согласува да му допушти на Сосија да каже што сака, сп. Pl.Am.389:

Merc. Immo indutiae parumper fiant, si quid vis loqui.

Мер. Напротив, примирје за момент нека биде, ако сакаш нешто да соопштиш.

На ова се надоврзува играта со зборови во стихот 393 каде што Сосија со реченицата nunc licet mihi libere quidvis loqui потврдува дека сега му е допуштено да го каже слободно тоа што сака да го каже, но во исто време кажува и дека ќе каже што тој би сакал Меркур да каже, затоа што формата libere може да биде и инфинитив од глаголот libet, „ми годи, ми се допаѓа, сакам“, но овде во смисла „посакувам, одбирам“. Така, стихот 393 може да се преведе и на следниов начин:

Внимавај ваму. Допуштено ми е сега да посакам што сакаш да соопштиш.

\section{Liber - lubet - licet - licentia - lex}

Направената анализа на стиховите од комедиите на римскиот комедиограф Плаут, во кои може да се препознаат звучни и семантички игри со зборовите изведени од основата lib-ero- покажува дека Плаут, од една страна, ги поврзува меѓусебно придавката līber, „слободен“ и нејзините изведенки lībertas, „слобода“, lībero, „ослободувам“, līberālis, „слободен, благороден, љубезен“, līberī, „деца“, Lìber, „Либер, Ослободител“, а од друга страна овие зборови ги става во контекст со други зборови како lepōs (lepor), „пријатност, нежност, слаткост“, lepidus, „пријатен, мил, нежен, сладок“, locus, „место, седиште“, licet, „допуштено е, може“, $l i$ bet, „ми се допаѓa, сакам“, lībella, „десетти дел од денариј, паричка“, loquor, „зборувам“, кои се блиски по звучност, но не се етимолошки поврзани со основата $l \bar{\imath} b$ ero-.

Кога предмет на игра се само зборови изведени од истата основа lib-ero-, најчесто станува збор за недоразбирање меѓу ликовите на сцената, кое е смешно, но има и некаква драмска функција во поглед на дејството или ликовите. Таков е случајот со игрите помеѓу зборовите liberalis и libero (Pl.Cur.208-209), liber и Liber (Pl.Capt. 577-578), liber и liberi (P1.Mil. 682-683).

\footnotetext{
${ }^{13}$ Licet е од протоиталската глаголска основа *lik-e-e, „на понуда е, достапно е, вреди, чини“ (види $E D L$ 340; Nussbaum, 1994 : 162 и понатаму), а loquor од протоиталскиот корен *tlok ${ }^{w}$-, „зборувам“, сп. стирс. adtluchedar, „се заблагодарува“ (види EDL 348-349, IEW 3 ).

${ }^{14} \mathrm{Vis}$ е форма за второ лице сегашно време од глаголот volo, „сакам“.
} 
Кога предмет на игра е вопоставувањето звучни и семантички релации помеѓу зборовите изведени од основата lib-ero- и други зборови етимолошки неповрзани со нив, тогаш забележлив е развојот на нови значења кај зборовите изведени од основата lib-ero-. Така, поврзувањето на придавките liber и liberalis со зборовите lepor и lepidus, libet и libentius овозможува кај нив покрај значењето „слободен, благороден“, да се развие и значењето „опуштен, отворен“.

Ако го погледнеме опсегот на значења на зборовите изведени од друга основа со кои Плаут ги доведува во врска придавката liber и нејзините изведенки, се покажува дека преку игрите со зборови поимот на слободата се поврзува со задоволството, желбите, парите, говорот, опуштеноста, виното. На оваа листа треба да се додадат и поимите закон, допуштено е, дозвола, лат. lex, licet, licentia. Употребата на licet и licentia во игрите со зборови кај Плаут беше предмет на анализа во трудот објавен во претходниот број, број 68 од Годишниот зборник на Филозофскиот факултет (Џукеска, 2016 : 77-80). Во оваа прилика да се потсетиме на стиховите од „Тригрошец“ во кои Плаут ја покажува амбивалентноста на тоа што е дозволено и слободно, сп. Pl. Trin. 1032-1035:

Stas. Nam nunc mores nihili faciunt quod licet, nisi quod lubet:

ambitio iam more sanctast, liberast a legibus;

scuta iacere fugereque hostis more habent licentiam:

petere honorem pro flagitio more fit...

„Денес е вообичаено да не се грижиш дал' е дозволено, ако е пожелно:

стремежот веќ ги има благословот на обичаите и слободата на законите;

Штитот да го фрлиш и од непријателот да бегаш дозвола ти даваат обичаите:

Почести да бркаш заради бесчестие стана обичај.“...

Имајќи ги предвид и останатите игри со зборови во кои Плаут ја употребува придавката liber, јасно е дека за анализата на овие стихови треба да се земе предвид и синтагмата liberast a legibus, која се однесува на именката ambitio, „стремеж, амбиција“. Кога стремежот ќе се ослободи од законите, а ќе му се потчини само на обичајот, а вообичаено е не тоа што е дозволено, туку тоа што е пожелно, посакувано, тогаш слободата се претвора во својата спротивност и станува самоволие.

Иако Плаутовите дела се само книжевен материјал, сепак, анализата на игрите со зборови покажува дека токму ова стилско средство може да биде важен извор на информации за тоа како старите Латини, го разбирале поимот слобода. 


\section{Литература}

Изворни и преводни изданија

T. Macci Plauti Comoediae, Tomus I, ed. W.M. Lindsay, Oxonii, 1988 (репринт на изданието од 1904).

T. Macci Plauti Comoediae, Tomus II, ed. W.M. Lindsay, Oxonii, 1990 (репринт на изданието од 1905).

Plautus, ed. T. E. Page et al., with an English translation by Paul Nixon, in five volumes, London - Cambridge, Massachusetts, reprinted 1980.

Плаут, Комедии (Менехми, Скржавецот, Трговец - превод од латински, М. Богески; Заробеници - препев од латински, М. Бузалковска Алексова), Скопје: Евробалкан прес, 2003.

Т. М. Плаут, Војникот фалбаиија (превод од латински, белешки и предговор М. Бузалковска-Алексова), Скопје: Профундум, 2007.

Т. М. Плаут, Сеништа (превод од латински, белешки и предговор Е. Џукеска), Скопје: Профундум, 2011.

\section{Друга литература}

на кирилица:

БЕР = В. Георгиев и др., Български етимологичен речник. I-VII, София: Издателство на БАН и Академично издателство „Проф. Марин Дринов“, 19712010.

Џукеска, 2016 : Џукеска, Е. „Licet, licet, licentia“, ГЗ на ФзФ 68, стр. 77-82.

на латиница:

Benveniste, 1969 : Benveniste, E., Le vocabulaire des institutions indo-européennes. 1. Économie, parenté, société, Paris: Les éditions de minuit.

$\mathrm{DELG}=\mathrm{P}$. Chantraine, Dictionnaire étimologique de la langue grecque, I-IV $\mathrm{V}_{2}$, Paris: Éditions Klincksieck, 1968-1980.

Duckworth, 1994 : Duckworth, G.E., The Nature of Roman Comedy: a study in popular entertainment (with a foreword and bibliographical appendix by Hunter, R.), sec.ed., Norman: University of Oklahoma Press.

$\mathrm{EDG}=\mathrm{EDG}=$ R.S.P. Beekes (with the assistance of L. van Beek), Etymological Dictionary of Greek, I-II, Leiden - Boston: Brill 2010.

$\mathrm{EDL}=\mathrm{M}$. de Vaan, Etymological Dictionary of Latin and the other Italic Languages, Leiden-Boston: Brill, 2008.

EDSIL $=$ R. Derksen, Etymological Dictionary of the Slavic Inherited Lexicon, LeidenBoston: Brill, 2008.

Fontaine, 2010 : Fontaine, M., Funny words in Plautine Comedy, Oxford: Oxford University Press. 
Fraenkel, 2007 : Fraenkel, E., Plautine Elements in Plautus, Oxford: Oxford University Press.

IEW $=$ J. Pokorny, Indogermanisches etymologisches Wörterbuch, I-II, Bern - München: Francke Verlag, 1959 - 1965.

Leumann, 1977 : Leumann, M., Lateinische Laut- und Formenlehre, München: C.H. Beck'sche Verlagsbuchhandlung.

McCarthy, 2000 : McCarthy, K., Slaves, Masters and the Art of Authority in Plautine Comedy, Princeton: Princeton University Press.

Meiser, 2006 : Meiser, G., Historische Laut- und Formenlehre der lateinischen Sprache, 2 Aufl, Darmstadt.

Mendelsohn, 1907 : Mendelsohn, Ch. J., Studies in the Word-Play in Plautus, Philadelphia: University of Pennsylvania.

Nussbaum, 1994 : Nussbaum, A. "Five Latin Verbs from a Root *leik-", Harvard Studies in Classical Philology 96, pp. 161-191.

OLD = A. Souter et al., Oxford Latin Dictionary, Oxford: Clarendon Press, 1968.

Stewart 2012 : Stewart, R., Plautus and Roman slavery, Malden, MA - Oxford: Wiley Blackwell.

Untermann, 2000 : Untermann, J., Wörterbuch des Oskisch-Umbrischen, Heidelberg: Universitatsverlag C. Winter.

Westaway, 1917 : Westaway, K. M., Original Element in Plautus, Cambridge: University Press. 
Elena DŽUKESKA

\section{THE ADJECTIVE LIBER AND ITS' DERIVATIVES IN PLAUTUS' WORD PLAYS}

\section{Summary}

The adjective līber, ,free, released, loose, unoccupied" from the Indoeuropean root * $H_{l} l e u d h-$, ,grow " and its derivatives lībertas, ,freedom ", lībertus and lībertīnus, „,freedman", lībero, ,free", līberālis, ,,free, noble, generous ", līberī, ,, children “, Līber, "Liber, Liberator" play significant role in creating wordplays in the works of the Roman comediographer Plautus. The analysis of the examples shows that these words on one hand were used by Plautus for creation of funny situations of misunderstanding, based on their polysemy. On the other hand Plautus puts them in a context with other words, that are not etymologically related, by sound similarly. This second type of wordplays is important testimony for the semantical development of the adjective liber and its derivatives in Old Latin, but also for an additional analysis of the understanding of the term , freedom " by Latins.

Keywords: LIBER, PLAUTUS, WORDPLAY 